\title{
Elevai os olhos para os montes: A cristologia do comentário agostiniano sobre Jo 1,1
}

\section{Lift up your eyes to the hills: The Christology of Augustin's comment on Jo 1:1}

\section{Resumo}

Os comentários de Agostinho sobre as Sagradas Escrituras demonstram a fecundidade da contribuição da Igreja Latina para a Teologia Patrística. No contexto das polêmicas cristológicas, surgem soluções que delimitam o campo de interpretação dos textos sagrados, condicionando a linguagem ortodoxa para que os discursos se adequassem à regra de fé estabelecida pelos concílios. No comentário agostiniano, o primeiro versículo do evangelho joanino tornase exemplo de como superar as dificuldades materiais da leitura do texto. Agostinho também oferece esquemas hermenêuticos onde as conclusões cristológicas de tal maneira dialogam com a eclesiologia e com a escatologia, que inspiram explicações originais e mais amplas do que aquelas elaboradas no contexto apologético precedente, onde o gnosticismo, o judaísmo e o arianismo representaram os maiores desafios para a interpretação do versículo. Desta maneira, Agostinho exorta os cristãos para que sigam o percurso de crescimento espiritual escondido nas palavras descritas pelo evangelista no início de sua obra.

Palavras-chave: João. Patrística. Agostinho. Cristologia. Eclesiologia.

\section{Abstract}

Augustin's commentaries on the Holy Scriptures are important to show 
the richness of initiatives which made a genuine contribution from the Western Church towards the Patristic Theology. In the context of Christological debates, we are able to see results that constrain the field of interpretation of the sacred texts, forging the orthodox way to say, so that the speeches could fit the regula fidei which the councils had established. In the Augustinian commentaries, the first verse of John's Gospel became a model of how to overcome material difficulties in reading the text. In addition, Augustin gives us hermeneutic clues through which we reach Christological conclusions so engaging in a constructive dialogue with Ecclesiology and Eschatology, that they may inspire us to look for original explanations that are wider than those provided by the former apologetic context, where Gnosticism, Judaism and the Arianism represented the biggest challenge to the interpretation of the verse. For that reason, Augustin exhorts the Christian to follow the path of spiritual growing hidden in those words that the Evangelist used to open his work.

Keywords: John. Patristics. Augustin. Christology. Ecclesiology.

\title{
Introdução
}

\author{
No princípio era o Verbo; \\ E o Verbo estava com Deus; \\ E Deus era o Verbo.
}

Com essas três sentenças, o prólogo joanino abre o quarto evangelho centralizando o discurso no Lógos Divino. Em forma de versos poéticos, ${ }^{1} \mathrm{o}$ versículo é marcado pela inversão da terceira frase, formando um quiasmo de valor místico que apenas os cristãos que admitiam a divindade do Verbo podiam compreender em sua profundidade. Ao mesmo tempo, não eram poucas as dúvidas que o mesmo versículo levantava para os leitores menos familiarizados com esse recurso.

Agostinho se dedicou com especial atenção para resolver aquelas questões que os textos bíblicos suscitavam dentro e fora da Igreja, encontrando nos recursos retóricos e nas tradições filosóficas da sua época instrumentos compatíveis com os ensinamentos da fé cristã. Ao

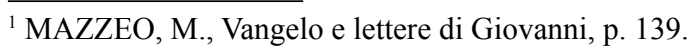


longo do seu ministério, sustentou uma teologia bíblica, cujas aparentes contradições dependiam do sistema de linguagem humana assumido pela iniciativa de Deus em revelar-se aos homens e às mulheres de uma forma que o pudessem compreender. A superação das aparentes contradições equivale ao caminho pelo qual o coração humano pode ser conduzido em direção à grandeza divina.

A utilidade de nos concentrarmos na hermenêutica agostiniana sobre Jo 1,1 pode ser verificada pelo fato de este versículo ser tomado pelo princípio metodológico agostiniano como exemplo das dificuldades materiais dos textos bíblicos, por representar um intenso e difícil discurso cristológico e pela originalidade que os comentários agostinianos produziram sobre o mesmo.

\section{O papel eclesiástico na publicação e na leitura dos textos bíblicos}

Os indícios que nos projetam para o contexto de vida da igreja primitiva tão vulneravelmente nos introduzem em circunstâncias diferentes das que conhecemos nos dias de hoje, que às vezes se torna fácil ignorar o quanto nos equivocamos em função dos valores contemporâneos que sobrepujamos. Por exemplo, sem uma adequada atenção sobre os protagonistas e sobre o processo pelo qual se produzia um escrito antigo, permanecemos desatentos em relação às conexões que algumas informações dos textos sagrados podem trazer.

Efetivamente, para que tomemos consciência do distanciamento a que estamo-nos a referir, basta que recorramos ao simples dever de comunicar ao sujeito midiático das plataformas e armazenamentos virtuais hodiernos que, por questões logístico-materiais, no quinto século da era cristã ainda eram extremamente raras as pessoas que poderiam ter em mãos uma coleção completa das Sagradas Escrituras, para compreender que as mudanças históricas construíram lacunas abissais entre nós e os primeiros cristãos. Nem as normativas canônicas, nem o esforço de Jerônimo em traduzir a Bíblia, nem tampouco os avanços tecnológicos na produção dos manuscritos foram responsáveis por um acesso imediato ao texto completo por escrito. Pelo contrário, ainda no tempo de Agostinho a maior parte das pessoas confiava na transmissão oral daquilo que se conhecia de cor, enquanto proporcionalmente poucos eram aqueles que procuravam os centros librários tais como as ilustres bibliotecas das grandes dioceses, as modestas coleções das igrejas particulares ou as compilações de alguns notórios personagens como o bispo 
de Hipona, para materialmente ler alguma coisa. ${ }^{2} \mathrm{O}$ próprio Agostinho sabia que as pessoas não gozavam do privilégio de ter em suas casas um exemplar completo das Sagradas Escrituras e que nem todas as pessoas as tinham lido. ${ }^{3}$ As habilidades mnemônicas mais desenvolvidas eram comuns também por causa dos limites físico e financeiro para construir um lugar onde fosse possível produzir, copiar, armazenar e conservar tais textos. Agostinho adverte que pode se tornar inexata a interpretação de alguém que confia mais na memória do que no texto escrito, criticando algumas pessoas pelo fato de jamais terem se preocupado em ler fisicamente o texto das Escrituras. ${ }^{4}$

No cerne da polêmica que Agostinho levanta contra os arianos sobre a interpretação de Jo 1,1 aparece uma referência aos aspectos materiais dos códigos - entenda-se manuscritos - que condicionavam a interpretação que os hereges faziam. Não possuímos estes códigos, mas, nesse sentido, talvez seja bastante útil recorrer ao fac-símile do fragmento Vat. lat. 10959, cópia de um texto de Cipriano de Cartago, cujas características servem como modelo para os manuscritos latinos que eram produzidos em ambiente africano entre o quarto e o quinto século. ${ }^{5}$ Encontramos, assim, o Vat. lat. 10959 com as seguintes dimensões em milímetros: 275 por 230; o texto foi disposto em duas colunas e inscrito com a caligrafia uncial old-style. ${ }^{6}$

A partir disso, temos mais elementos para entender o que Agostinho afirma, quando repreende os arianos, ao dizer:

Consideremos alguns exemplos. Seja o primeiro, o de uma pontuação que leva à heresia: In principio erat Verbum et Verbum erat apud Deum et Deus erat. O ponto final aí colocado muda o sentido da frase. Porque a continuação: Verbum hoc erat in principio apud Deum não leva a reconhecer que o Verbo era Deus. Tal pontuação deve ser rejeitada em virtude da regra de fé que nos prescreve confessar a igualdade da Trindade. Pontuaremos, portanto, deste modo: Et Deus erat Verbum, acrescentando logo a continuação: hoc erat in principio apud Deum. ${ }^{7}$

A referência à possibilidade de Agostinho ter lido um texto com um

\footnotetext{
${ }^{2}$ CHERUBINI, P., Forme e modelli della tradizione manoscritta della Bibbia, p. 35 .

${ }^{3}$ AGOSTINHO, In Ev. Ioan. 41, 6; 28, 3.

${ }^{4}$ AGOSTINHO, Contra Maximum II, 23, 3.

${ }^{5}$ CHERUBINI, P.; PRATESI, A., Paleografia Latina, p. 15, tavola 15.

${ }^{6}$ CHERUBINI, P.; PRATESI, A., Paleografia Latina, p. 15, tavola 15.

${ }^{7}$ AGOSTINHO, De doct. Christ. III, 2, 3.
} 
sistema de pontuação que só haveria de ser desenvolvido a partir do nono século $^{8}$ gera um crasso equívoco de tradução. $O$ problema não consiste em pontuar o texto, mas nas pausas de leitura que devem ser respeitadas pelos leitores que quiserem entender o verdadeiro significado do texto. $\mathrm{Na}$ verdade, essa citação acima alude simultaneamente a três questões: o texto em grego que Ário e seus seguidores liam; o texto latino que Agostinho e seus interlocutores conheciam; a leitura ortodoxa dos mesmos textos. Por ora, nós nos debruçamos sobre as duas últimas questões.

Em primeiro lugar, se consideramos o fragmento Vat. lat. 10959, observamos que, sem pontuação, sem espaçamento entre palavras e sem abreviações desnecessárias, em cada linha do manuscrito cabem entre dezessete e vinte letras, segundo a largura desproporcional de cada letra. Como se trata do início do Evangelho de João, é razoavelmente provável que a primeira letra da primeira linha também estivesse posicionada sem qualquer antecedente à margem esquerda superior no manuscrito a que Agostinho se refere. Dessa forma, levantamos algumas hipóteses sobre a disposição do texto citado pelo bispo hiponense:

Hipótese 1:

Dezessete letras por linha

INPRINCIPIOERATVE

RBUMETVERBUMERATA

PUDDEUMETDEUSERAT

VERBUMHOCERATINPR

INCIPIOAPUDDEUM

Hipótese 3:

Número intercalado de letras por linha, começando com dezessete letras:

INPRINCIPIOERATVE

RBUMETVERBUMERATAPUD

DEUMETDEUSERATVER

BUMHOCERATINPRINCIPI

OAPUDDEUM
Hipótese 2:

Vinte letras por linha

INPRINCIPIOERATVERBU

METVERBUMERATAPUDDEU

METDEUSERATVERBUMHOC

ERATINPRINCIPIOAPUDD

EUM

Hipótese 4:

Número intercalado de letras por

linha, começando com vinte letras:

INPRINCIPIOERATVERBU

METVERBUMERATAPUD

DEUMETDEUSERATVERBUM

HOCERATINPRINCIPI

OAPUDDEUM

\footnotetext{
${ }^{8}$ BISCHOFF, B., Paleografia Latina, p. 240.
} 
Levando em consideração que Agostinho insista que a leitura que deve ser feita é Et Deus erat Verbum, conjecturamos que, com baixa probabilidade, os manuscritos latinos daquele período devem ter sido transmitidos de acordo com a hipótese 2 ou com a hipótese 4, pois, estes tipos de agrupamento das palavras teriam diminuído ou evitado de vez as contínuas polêmicas com os arianos latinos sobre esse versículo. Pelo contrário, a interpretação cristológica se torna mais complexa a partir do modelo da hipótese 3 e completamente difícil diante da primeira hipótese. Com isso, aquela distinção herética (illa haeretica distinctio) que os arianos faziam para defender um sentido diverso (ut alius sit sensus) $)^{9}$ possivelmente encontrava apoio nos manuscritos latinos do quarto e do quinto séculos.

Em segundo lugar, abordando aquela questão sobre a leitura ortodoxa dos textos, é possível notar que Agostinho não apenas use a regra de fé como instrumento definitivo para interpretar Jo 1, 1, mas também transforme este versículo num marco referencial para a verdadeira e segura interpretação da doutrina cristã em geral.

Em suas explicações, busca convencer os seus interlocutores que, uma vez que se encontra em uma ambiguidade (ambiguitas) teológica gerada por causa dos textos bíblicos, alguns problemas poderão ser resolvidos pela comparação linguística do próprio texto em outras versões, ${ }^{10}$ mas outros devem ser esclarecidos pelo seu contexto, ${ }^{11}$ enquanto outros só se explicam pela regra de fé12 que a Igreja define. Como as afirmações dos arianos se pautavam sobre o caráter material do texto, Agostinho concluiu que o melhor modo de sanar a dúvida daquele texto era confiando na regra de fé que definira indubitavelmente a coeternidade do Filho junto com o Pai no Concílio de Niceia. ${ }^{13}$

No mesmo vagão puxado por esta locomotiva da regra de fé, Agostinho vê a unidade hermenêutica se movimentar em três modalidades diferentes, por depender da centralidade de Cristo nas Sagradas Escrituras. Para Agostinho, é evidente que o Antigo e o Novo Testamento - voluntariamente citando a Lei,

\footnotetext{
${ }^{9}$ AGOSTINHO, De doct. Christ. III, 2, 3.

${ }^{10}$ AGOSTINHO, De doct. Christ. III, 3, 6 .

${ }^{11}$ AGOSTINHO, De doct. Christ. III, 3, 7.

${ }^{12}$ AGOSTINHO, De doct. Christ. III, 2, 5.

${ }^{13}$ Agostinho desempenha um papel fundamental para a implantação e divulgação da questão ariana em ambiente latino. Sugerimos o artigo no qual Simonetti trata em detalhes sobre as inovações da apreciação que Agostinho faz de toda contenda. SIMONETTI, M., Studi di Cristologia Postnicena, p. 291-323.
} 
os Profetas, as cartas dos Apóstolos e os Evangelhos - são unânimes ao falar de Cristo, não obstante o fato de usarem aquelas três formas diferentes de falar: o primeiro modo se abstrai das Escrituras segundo a divindade coeterna e consubstancial ao Pai antes da Encarnação; o modo de descrevê-lo depois da Encarnação - segundo da lista - versa sobre as afirmações onde a divindade e a humanidade estão unidas por certa propriedade de sua excelência (secundum quandam suae excellentiae proprietatem), ou seja, pelo fato de assim ser chamado mediador e cabeça da Igreja; no terceiro e último modo bíblico de falar, Cristo aparece como plenitude ou como homem perfeito - segundo a perspectiva escatológica - de quem nós já somos membros. ${ }^{14}$

Repetiu o que já havia dito no sermão antecedente:

Nosso Senhor Jesus Cristo - do quanto as santas páginas nos permitiram entender - de três maneiras é compreendido e nomeado quando fora anunciado seja através da Lei e dos Profetas, seja através das Epístolas Apostólicas, seja através da fé cujas façanhas (per fidem rerum gestarum quas) conhecemos no Evangelho. A primeira maneira [de conhecê-lo] se dá segundo Deus e segundo aquela divindade coetânea e coeterna ao Pai antes de ter assumido a carne. Outra maneira [de conhecê-lo] se dá depois que a carne foi assumida [porque] já aquele Deus que é homem é também o mesmo homem que é Deus, segundo determinada propriedade pela qual, de sua excelência, não é equiparado aos demais homens, mas se torna mediador e cabeça da Igreja, como assim se lê e se entende. A terceira maneira [de conhecê-lo] se dá pelo modo em que Cristo é tudo [ou tão grande] na plenitude da Igreja, ou seja, cabeça e corpo, segundo a plenitude do homem verdadeiramente perfeito; homem no qual somos, cada qual, membros (tradução nossa). ${ }^{15}$

A Igreja, juntamente com os seus filhos, percorre com segurança a trajetória dessa unidade de fé e dessa diversidade hermenêutica, sem o risco de descarrilamento. Agostinho, de fato, aplica estes três modelos hermenêuticos, pelos quais procura os significados cristológicos a partir do conteúdo sobre a Trindade, a Eclesiologia e a Escatologia ao mesmo tempo. Em resumo, diz-se de Cristo quer na perspectiva Pai-Filho segundo Deus e sua divindade (secundum Deum et divinitatem illam Patri coaequalem atque coaeternam), quer na perspectiva Mediador-Cabeça segundo a sua propriedade (secundum

\footnotetext{
${ }^{14}$ AGOSTINHO, Serm. 341 augm. 2 [1].

${ }^{15}$ AGOSTINHO, Serm. 341 1, 1.
} 
quamdam proprietatem), quer na perspectiva Cabeça-Corpo segundo a sua plenitude (secundum plenitudinem), sem que esses modelos possam contradizer um ao outro. Pelo contrário, realizam a mais profunda unidade do mistério sagrado. Num determinado comentário, para dar um exemplo, quer responder por que, no mesmo capítulo, João, Evangelista, chama Cristo de pastor e de porta, tomando curiosamente Jo 1,1 a partir da segunda regra (secundum proprietatem), onde, na verdade, esperar-se-ia a aplicação da primeira:

Há muito mais diferenças entre o pastor e a porta, do que entre o porteiro e a porta. Mesmo assim, o Senhor afirmou [sobre si mesmo] que fosse tanto o pastor quanto a porta. Por que, então, não lemos que ele também seja porteiro? De fato, se consideramos [ess]as propriedades, Cristo Senhor nem é pastor - como os pastores que normalmente conhecemos e vemos -, nem tampouco é porta, já que nenhum artesão o tenha feito. No entanto, se segundo alguma semelhança é tanto porta quanto pastor, ouso dizer que ele também seja ovelha. Seguramente, a ovelha está sob os cuidados do pastor, mas, no entanto, ele é pastor e é também ovelha. De onde se conclui que seja pastor? Eis que leia o Evangelho aquele que o tiver: Eu sou o bom pastor. De onde se conclui que seja ovelha? Interrogue o profeta [aquele que o tiver]: como ovelha foi levado ao matador. Interrogue o amigo do esposo [aquele que o tiver]: Eis o cordeiro de Deus, eis aquele que tira o pecado do mundo. A respeito destas semelhanças, hei de dizer algo ainda mais admirável. O cordeiro, a ovelha e o pastor entre si até são amigos. Além disso, as ovelhas normalmente são tuteladas pelos pastores contra os leões. Entretanto, sobre Cristo, a quanto possa ser ovelha ou pastor, lemos também o que foi dito: Venceu o Leão da tribo de Judá. Irmãos, compreendei todas essas coisas segundo as semelhanças (secundum similitudines), não segundo as propriedades (non secundum proprietates). Normalmente vemos que os pastores se sentam sobre a pedra, e [notamos que] dali eles vigiam a ovelha, depois que essa lhes fora confiada. De qualquer maneira, o pastor é melhor do que pedra sobre a qual se senta o pastor e, contudo, Cristo é pastor e é também pedra. Tudo isso [se dá] segundo a semelhança. A propriedade [darei], se a quiserdes, no entanto, de mim: In principio erat Verbum et Verbum erat apud Deum et Deus erat Verbum. Se me perguntardes sobre a propriedade, [respondo] que é o Unigênito Filho do Pai desde sempre para sempre, igual àquele que o gerou, por meio de quem todas as coisas foram feitas, incomutável com o Pai, aquele que não mudou pelo fato de ter aceitado a forma de homem, 
homem em virtude da encarnação, Filho do homem e Filho de Deus. Tudo isso que falei não é semelhança, mas é a realidade (tradução nossa). ${ }^{16}$

Uma vez que o Verbo é o mesmo que se tornou "o cordeiro, a ovelha e o pastor", em Jo 1,1 o leitor não encontra apenas uma faceta do Verbo, mas se depara com a realidade completa, ou seja: sua divindade, sua propriedade e sua plenitude. Esta cristologia agostiniana está em consonância com diversos esquemas teológicos que, desde os primórdios do cristianismo, sincronizavam os títulos messiânicos na tentativa de acomodar os valores que eram procurados num sistema complementar de significado. Por isso, não surpreende o fato que a tão almejada descoberta da proprietas cristológica possa ter tranquilamente assumido valores complementares, sem que necessariamente fossem contraditórios. Seguindo a lógica agostiniana, para ser legitimamente coeterno tem que ser mediador e pleno; para ser legitimamente mediador, não pode deixar de ser coeterno nem pleno; para antevê-lo legitimamente pleno, a principal condição tem que ser aquela de considerá-lo coeterno e mediador. Essas realidades ou propriedades pelas quais humanamente o Senhor pode ser conhecido são capazes de lançar luz uma sobre as outras, no processo de descoberta da profundidade do mistério revelado.

É oportuno lembrar que um dos objetivos principais do De Trinitate era o de encontrar a propriedade das operações cada Pessoa da Santíssima Trindade, para espiritualmente corrigir os erros dos homens arrogantes, ${ }^{17} \mathrm{o}$ que fez com que aquela obra se transformasse em uma empreitada existencial. ${ }^{18}$ Os maiores erros das almas prepotentes consistiam em atribuir a Deus ou aquilo que é próprio das criaturas visíveis, ou aquilo que é próprio das criaturas sobrenaturais, ou aquilo que não pode ser encontrado nem no mundo visível nem no mundo invisível. ${ }^{19}$ A partir disso, Agostinho chega a duas conclusões que devem nos ajudar na reflexão destas páginas: em primeiro lugar define que a missão própria (missio, proprium, proprietas) do Filho é a Encarnação ${ }^{20} \mathrm{em}$ segundo lugar, acrescenta mais três princípios hermenêuticos cristológicos, dizendo que ora as Sagradas Escrituras falam da natureza divina segundo a

\footnotetext{
${ }^{16}$ AGOSTINHO, In Ev. Ioan. 46, 3.

${ }^{17}$ AGOSTINHO, De Trin. I, 2, 4. TRAPÈ, A., I termini "natura" e "persona" nella teologia trinitária di S. Agostino, p. 577.

${ }^{18}$ STUDER, B., Austitinus De Trinitate, p. 48.

${ }^{19}$ AGOSTINHO, De Trin. I, 1, 1.

${ }^{20}$ AGOSTINHO, De Trin. II, 5, 8.
} 
qual o Filho é igual ao Pai (secundum Dei formam), ora falam da natureza de servo segundo a qual o Filho quis se fazer inferior ao Pai, ao Espírito Santo e até a si mesmo (secundum servi formam), ora não aludem nem à primeira nem à segunda opção, gerando dúvidas se isso possa se tratar da superioridade da natureza divina ou da inferioridade assumida na natureza de servo. ${ }^{21}$

\section{Interpretações apologéticas relevantes}

Mosetto defende que, ao invés de procurar sempre as mesmas explicações no nível de definições padronizadas, definitivas e fossilizadas, Agostinho tenha, na verdade, acumulado diferentes soluções sobre um mesmo tema bíblico. ${ }^{22}$ Descreveu que os principais fatores para a mudança de opinião do bispo de Hipona eram os contextos ou as audiências que tinha diante de si, sentindo-se mais livre fora do ambiente das polêmicas teológicas, onde podia de maneira natural dedicar-se à reflexão mais aprofundada da fé. ${ }^{23}$ Se assim Agostinho o faz, tomando por objeto de análise as diversas explicações hermenêuticas sobre a mistura da saliva com a terra para a cura do cego que aparece no capítulo nove do Evangelho de João, muito mais deve ter aprofundado sobre o Verbo Encarnado e sobre a sua pré-existência.

Os primeiros séculos da história do Cristianismo foram marcados por um período de amadurecimento e, simultaneamente, de sobrevivência da fé cristã diante de inúmeras opiniões contrárias ou heterodoxas, carimbando a literatura produzida neste período com apelo apologético. Pelo menos três contextos desta época podem ser relevantes para a leitura de Jo 1,1: o gnosticismo, o judaísmo helenístico e o arianismo.

Assim encontramos o contexto hostil onde se presume que a cristologia joanina se concilia com as ideias gnósticas do início do segundo século, pois, quando não gerou nos cristãos a suspeita contra a linguagem adotada pelo evangelista, inibiu amplamente a sua divulgação nos anos sucessivos à sua compilação, pelo menos de maneira literária. A ausência de referências joaninas, por exemplo, em Santo Inácio e em São Policarpo produz uma série de dificuldades para os historiadores. ${ }^{24}$ No entanto, preserva-se nos Padres Apostólicos a ideia de como a divindade ou a natureza divina exercem uma

\footnotetext{
${ }^{21}$ AGOSTINHO, De Trin. II, 1, 2.

${ }^{22}$ MOSETTO, F., Esegesi agostiniana di Gv 9, p. 479.

${ }^{23}$ MOSETTO, F., Esegesi agostiniana di Gv 9, p. 474.

${ }^{24}$ KOESTER, H., Gospels and Gospel Traditions, p. 33.
} 
função determinante na Encarnação do Senhor do mesmo modo como é tratado em Jo $1,1{ }^{25}$ Isso significa que, embora Santo Inácio e São Policarpo não tenham citado textualmente o Evangelho de São João, eles empregaram conceitos teológicos cuja origem pode ser explicada em função do contato que teriam tido com o texto joanino. De fato, o Evangelho de João em seu conjunto se diferencia dos Sinóticos - segundo Kysar - também por ser um texto elaborado para os cristãos que já haviam passado da primeira fase de instrução catequética, assumindo, por isso, uma linguagem tipicamente arcana, mais elevada e, em última análise, gnóstica. ${ }^{26}$

Coincidentemente, "Princípio", "Verbo" e "Deus" - os termos principais de Jo 1,1 - hão de passar por um processo de personificação dentro do esquema valentiniano e na escola de Ptolomeu, na tentativa de classificar uma teologia pluralista e politeísta, determinada pelas emanações de um pleroma cujo mediador serviu para que se espalhassem confusões entre Cristo e o Demiurgo. ${ }^{27}$ Irineu de Lião informa que mesmo entre os gnósticos as controvérsias que surgiam resultavam em desentendimentos acerca do Salvador. ${ }^{28}$ Para Lactâncio o problema envolvia também os filósofos e os promotores do politeísmo pagão, colocando em questão a divindade do Verbo Encarnado em sua primazia diante da criação e, assim, demonstrando que tal veneração seria indevida para quem não tivesse criado o homem. ${ }^{29}$ Em suma, o gnosticismo, grande parte dos filósofos e a religião pagã se aproximam uns dos outros no tocante às opiniões pelas quais se tentava explicar o papel do Logos Divino na criação.

Nos círculos mais intelectualizados do judaísmo helenizado encontramos expressões que se distanciaram do rigor monoteísta. Desse modo - na opinião de Borgen - Filão de Alexandria representa um judaísmo helenizado bastante próximo dos autores do Novo Testamento que tiveram que lidar com o tema do Verbo divino na criação. Consideradas as diferenças entre o cristianismo nascente e o judaísmo clássico, é útil saber que Filão e João se apropriam, da

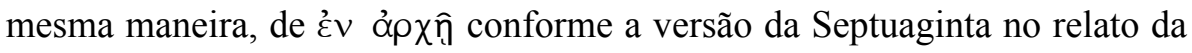
criação (Gn 1,1). Além disso, Filão também passa da palavra pronunciada por Deus em Gn 1,3 (Deus disse...) para chegar no Lógos Divino como modelo

\footnotetext{
${ }^{25}$ WEINANDY, T. G., The Apostolic Christology of Ignatius, p. 76.

${ }^{26}$ KYSAR, R., Giovanni, il vangelo indomabile, p. 203.

${ }^{27}$ IRINEU DE LIÃO, Adv. Haer. I, 11, 1; I, 12, 3.

${ }^{28}$ IRINEU DE LIÃO, Adv. Haer. I, 12, 4.

${ }^{29}$ LACTÂNCIO, Inst. Div. IV, 4, 9.
} 
(тò $\pi \alpha \rho \alpha ́ \delta \varepsilon ı \gamma \mu \alpha$ ) para a criação, onde consegue pensar em certa hipóstase personificada para o próprio Lógos. ${ }^{30}$

Orígenes se levanta para opor-se contra os gnósticos, investigando nas páginas sagradas do Antigo Testamento, como tinha feito a tradição judaicohelenística precedente, os sentidos que as Escrituras poderiam oferecer. Escreveu, assim, o primeiro e importante comentário patrístico sobre o Evangelho de João. Nessa obra, ao se perguntar qual seria o significado bíblico

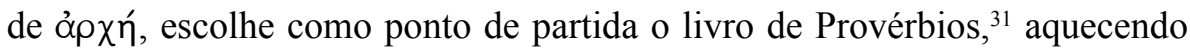
e preparando o debate para os futuros concílios. Entende-se, assim, o Cristo como ỏpxń por seis razões.

Em primeiro lugar, o bom caminho também precisa ser entendido como o mais longo, cujo termo será configurado pela destruição do último inimigo, a morte (1Cor 15,25), e pela perfeita transformação dos homens que culmina no conhecimento do Pai como o Filho o conhece. Explorando este sentido,

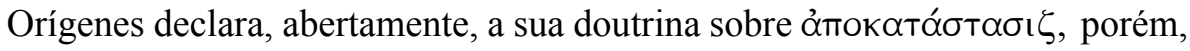
não sabemos se, neste momento, ele introduz a ideia de uma renovação universal de todas as coisas ou se esteja concebendo que apenas aqueles que hão de se salvar poderiam receber tal graça. $O$ texto pende mais para a segunda hipótese. Outrossim, a polêmica acabou por reduzir a questão à dimensão

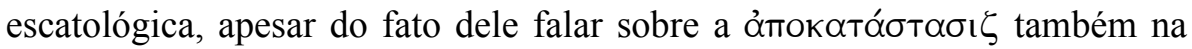
perspectiva antropológica e, sobretudo, cristológica. Em segundo lugar, o Verbo desempenha a tarefa de mediador entre Deus e as criaturas, entre as coisas invisíveis e visíveis, não apenas como Verbo, mas também como Filho e Princípio. Na terceira explicação, descarta a teoria filosófica de uma matéria

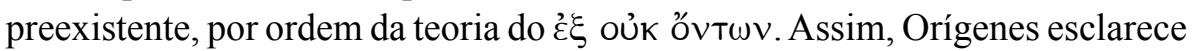
que as criaturas feitas por Deus tenham sido criadas ex nihilo, mas não elucida qual seja a relação entre o Verbo e as criaturas dentro deste argumento. $\mathrm{O}$ fato é que o Concílio de $\mathrm{Niceia}^{32}$ declarou como anátema todo aquele que dissesse

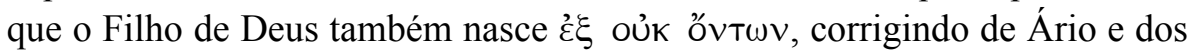
seus seguidores a opinião pela qual afirmavam que o Filho de Deus fosse uma criatura. Pelo quarto significado que Orígenes encontra para $\alpha \rho \chi \eta ́$, Cristo é designado como o $\alpha \alpha \theta^{\prime}$ o ô ov das criaturas, numa analogia de exuberante valor

${ }^{30}$ BORGEN, P., The Gospel of John, p. 46.

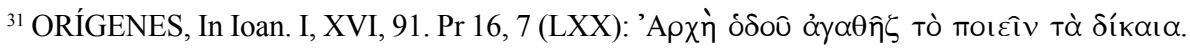
O princípio do bom caminho é o cumprimento das coisas justas (tradução nossa).

${ }^{32} \mathrm{DH}$ 126. Orígenes cita o texto bíblico de $2 \mathrm{Mc}$ 7, 28 e o texto patrístico de Herm. Past. Mand. I, 1; Vis. I, 1, 16. 
que cruza $\mathrm{Gn}$ 1,26-27 e $\mathrm{Cl}$ 1,15. Se os homens existem segundo a imagem e a imagem existe segundo o Pai, isso significa que, da mesma maneira que o "segundo aquilo que" ( $\kappa \alpha \theta$ ' oíov) de Cristo tem que ser o Pai, assim também o "segundo aquilo que" ( $\kappa \alpha \theta$ " oíov) das criaturas tem que ser o Cristo. ${ }^{33}$

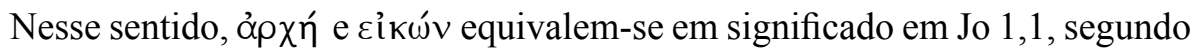
Orígenes. A divindade e humanidade de Cristo aparecem no quinto significado,

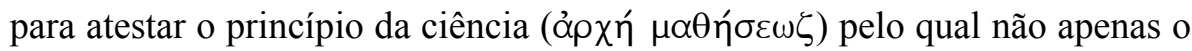
Verbo está em Deus, mas também se revela aos homens. Aprofundaremos esse princípio em Agostinho. O último significado classifica o Verbo Divino como princípio das ações do Pai, mostrando que Deus criou todas as coisas com Sabedoria, que é o nome próprio de Cristo.

A necessidade da proclamação dogmática em resposta ao arianismo levou a Igreja ao auge do processo de desescatologização e des-historização, determinando séculos da reflexão cristológica, que abandonava os muitos métodos deixados no passado para pautar-se na leitura ontológica da fé. ${ }^{34}$

No De Incarnatione Verbi, Atanásio está mais preocupado em citar Jo 1,14 do que Jo 1,1. Não aparece a citação do primeiro versículo. Todavia, é inevitável que ele mesmo se questione sobre a utilidade de falar da origem do mundo antes de apresentar a sua doutrina sobre a Encarnação do Verbo. Assim responde:

De fato, é necessário, quando falamos sobre a manifestação do Salvador

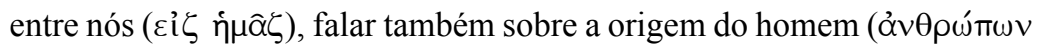

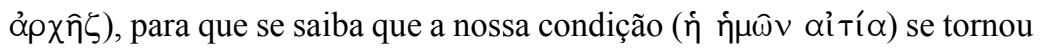
para ele a razão da sua descida, e que a nossa transgressão suscitou o

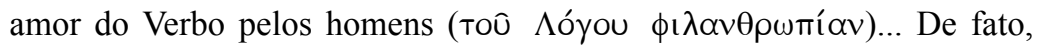
nós nos tornamos a premissa (úmó $\theta \varepsilon \sigma \iota \zeta)$ da sua encarnação e, pela nossa salvação, mostrou-se propenso a tornar-se homem e manifestar-se na carne (tradução nossa). ${ }^{35}$

Depois de descartar a possibilidade de Cristo ser conhecido como um Demiurgo segundo o que propunham os opositores dos cristãos, ${ }^{36}$ Atanásio

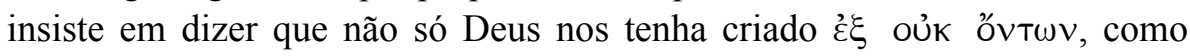

\footnotetext{
${ }^{33}$ ORÍGENES, In Ioan. I, XVI, 105.

${ }^{34}$ CANTALAMESSA, R., Dal kerygma al dogma, p. 21-27.

${ }^{35}$ ATANÁSIO DE ALEXANDRIA, De In. Verb. 4, 2-3.

${ }^{36}$ ATANÁSIO DE ALEXANDRIA, De In. Verb. 2, 1-3.
} 
também que tenha nos dado a graça de viver segundo o próprio Deus pela

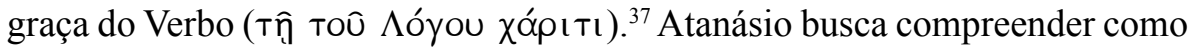
seja possível a mediação do Verbo Divino na criação, sem que lhe seja dada a categoria de criatura.

Com essa breve consideração sobre as primeiras polêmicas cristológicas, entendemos o quanto isso tenha sido determinante para reduzir o campo de interpretação de Jo 1,1, pois as grandes questões se concentravam em responder qual era a relação de Cristo com a criação. Em Agostinho é possível encontrar outra proposta.

\section{Comentário Agostiniano}

A abertura do In Evangelium Ioannis tractatus centum viginti quatuor sugere que Agostinho tenha pronunciado o seu comentário ao Evangelho de João dentro da liturgia, mais especificamente logo após a leitura do texto do Apóstolo, como ele menciona. ${ }^{38} \mathrm{O}$ contexto imediatamente não apologético permite a Agostinho mais liberdade na sua interpretação do texto, embora tenha se mostrado familiar às questões polêmicas. ${ }^{39}$ Insinua que seja algo que o Senhor lhe tenha inspirado a dizer, o que nos permite presumir que aquilo que estava por dizer não era fruto de uma intuição espontânea, mas provavelmente nascia de sua meditação e de sua oração.

Agostinho não se preocupa com o significado das palavras "Principium", "Verbum" ou "Deus". Na verdade, ele parte da constatação que há, naquela assembleia litúrgica, irmãos com diferentes graus de entendimento das Escrituras. Refere-se a uns como se pudessem entendê-lo, mesmo antes que ele terminasse a explicação. Refere-se a outros como se não o entendessem. Esse é o núcleo de uma interpretação extremamente original, enquanto the permite construir uma explicação com bases eclesiológicas para Jo 1,1. O ponto de partida é o autor do texto, ou seja, segundo Agostinho, o Apóstolo João, de quem Agostinho diz:

No final, a misericórdia de Deus há de se fazer presente para que a todos [que compreendem e não compreendem] isso se dê de maneira satisfatória

\footnotetext{
${ }^{37}$ ATANÁSIO DE ALEXANDRIA, De In. Verb. 5, 1.

${ }^{38}$ AGOSTINHO, In Ev. Ioan. 1,1.

${ }^{39}$ AGOSTINHO, In Ev. Ioan. 1,11: Agostinho menciona o erro dos arianos e o então clássico paralelo entre a expressão "in principio" de Gn 1,1 e Jo 1,1.
} 
e cada um possa entender o que lhe for possível, já que mesmo aquele que fala, diz só aquilo que pode dizer. Na verdade, quem é que pode dizer $o$ que existe de fato (ut est)? Ouso afirmar, meus irmãos, que talvez nem o próprio João tenha dito o que de fato existe (ut est), mas [disse] apenas $o$ que podia dizer (ut potuit) [sobre o que de fato existe], por que era sobre Deus que o homem falava. Mesmo sendo inspirado por Deus, permanecia sempre o fato de ser homem. Disse algo, porque era inspirado; se não fosse inspirado, não seria capaz de dizer alguma coisa. Não disse tudo aquilo que há pra dizer (totum quod est), em consonância com o fato de ser homem inspirado, mas disse apenas aquilo que o homem podia (quod potuit) dizer (tradução nossa). ${ }^{40}$

Agostinho escapa dos conceitos criados pelo rigorismo ontológico, por reconhecer a limitação da linguagem humana diante do mistério sagrado. O período da sua vida é influenciado pela busca que os primeiros concílios ardorosamente fizeram para encontrar o quod est cristológico. Esse era o tom dado pelas investigações desde o concílio de Niceia (325) até pelo menos o concílio de Constantinopla III (681). Todavia, surge Agostinho que, neste tratado, propõe o quod potuit dicere.

É honesto dizer que, se houve algum tipo de limitação histórica na abordagem cristológica, isso não tenha acontecido em função do quod potuit dicere, mas certamente em vista dos equívocos de uma pretensa redução do quod est da investigação ontológica à maneira de como se podia dizer, ou seja, ut potuit dicere. Nesse caso, enquanto o contexto apologético não permaneceu inibido, impondo limites para a compreensão teológica, Agostinho rumava para estratos de conhecimento menos sufocantes.

É muito comum e frequente nas obras de Agostinho o apelido pelo qual o bispo de Hipona costuma chamar são João Evangelista. Usa o apelido "montanha" (mons). Nós hoje usaríamos esse apelido para falar de pessoas altas e fortes. Não é o sentido que encontramos em Agostinho. Na sequência do comentário, descobrimos que esse apelido nasce da mesma comparação eclesiológica a que nos referimos anteriormente. Na Igreja há os montes e as colles. O Salmo 72 (71), 3 afirma: "Montanhas e colinas, trazei a paz ao povo. Com justiça ele julgue os pobres do povo". Na versão conhecida por Agostinho as montanhas acolhem a paz, enquanto as colinas recebem a justiça. Na obra em que comenta este Salmo, Agostinho explica que montes

${ }^{40}$ AGOSTINHO, In Ev. Ioan. 1, 1. 
e colles dizem respeito aos grandes e pequenos dentro da Igreja. Os grandes, designados não pela própria soberba, mas pela santidade de vida, são as montanhas. As colinas são os pequenos que seguem os grandes com docilidade para chegarem à salvação eterna. ${ }^{41}$ No progresso dos que pretendem alcançar o cimo da montanha, podem surgir pedras que os fazem naufragar. ${ }^{42}$ Nesse sentido, Agostinho chega à conclusão de que a justiça que as colinas acolhem significa o comportamento dos pequenos que não devem antepor os servos de Deus ao Senhor, nem jamais colocá-los ao mesmo nível do Senhor. Segundo o texto bíblico, devem elevar os seus olhos para os montes, de onde vem o socorro que precisam. Todavia, não devem esperar que estes montes se tornem o socorro que buscam e precisam. Os pequenos esperem no Senhor, que fez o céu e a terra. ${ }^{43}$

O núcleo da cristologia agostiniana sobre Jo 1,1 é norteado pelo binômio Cristo-Igreja, conforme apresentamos acima. A intuição de Agostinho o leva a constatar que as palavras "In principio erat Verbum, et Verbum erat apud Deum, et Deus erat Verbum" são tão sublimes em relação ao que se referem, que exigem a revelação divina através dos instrumentos pelos quais os homens podem chegar a tão grande mistério. Por isso, Agostinho convida a sua plateia a elevar os olhos para a montanha, sugerindo que pudessem mover seus corações em direção ao evangelista e à compreensão daquilo que esse pôde contemplar, sem, no entanto, colocar a esperança naquele homem. ${ }^{44}$ Assim acontece com os demais autores bíblicos. Nesse sentido, continua:

Nossos olhos, quando os levantamos para as Escrituras, na medida que por meio de homens nos foram entregues as mesmas Escrituras, nós estamos elevando os nossos olhos para as montanhas, de onde vem o nosso auxílio. No entanto, propriamente pelo fato de serem homens aqueles que escreveram as Escrituras, não reluziam por si mesmos, mas [o Verbo] era a luz verdadeira, que ilumina todo homem que vem a este mundo (Jo 1, 9). Era uma montanha também ele, João Batista, que dizia: 'não sou eu o Cristo', para que não se afastasse daquele que ilumina as montanhas quem quer que colocasse a sua esperança na montanha..$^{45}$

\footnotetext{
${ }^{41}$ AgOSTINHO, En. in Psalm. 71, 5.

${ }^{42}$ AGOSTINHO, In Ev. Ioan. 1, 3.

${ }^{43}$ AgOSTinHO, En. in Psalm. 71, 5.

${ }^{44}$ AGOSTINHO, In Ev. Ioan. 1, 6.

${ }^{45}$ AGOSTINHO, In Ev. Ioan. 1, 6.
} 
A partir de Jo 1, 1 e com marcas de uma mesma aquarela, Agostinho pincela o Verbo Eterno como luz soberana e resplandecente sobre as montanhas e como sombra projetada sobre as colinas. Em certa homilia, Agostinho considera relevante toda vez que os Evangelhos apresentam Jesus Cristo sobre o monte, pois isso ressaltaria que o Verbo está sempre no alto. ${ }^{46}$ Da grandeza e majestade divinas, o maior de todos os homens só teria conseguido alcançar que Deus fosse imutável, por compará-lo às criaturas mutáveis, descuidando-se do quod est divino, de fato. ${ }^{47}$ Esses são os limites humanos, mas também na pequenez da alma humana encontrase a grandeza do Verbo. É o Verbo que permanece como paz e justiça no coração dos pobres e pequenos, como sugere o Salmo 72. É como uma palavra que passa, depois de ser pronunciada, mas que deixa o seu significado na mente de quem a pronunciou e de quem a ouviu. ${ }^{48} \mathrm{Na}$ mente e no coração dos pequenos permanece o Verbo Eterno. Permanece ali, porque quis definitivamente fazer-se pequeno.

Em conclusão, o mistério da Encarnação efetivamente determina o percurso pelo qual é possível para o homem sair de sua pequenez para chegar à grandeza divina. Quem negou que o Verbo fosse eterno, mesmo depois de ter ouvido "In principio erat Verbum", concluiu que fosse uma criatura, por não entender o motivo pelo qual o Verbo Eterno tinha se encarnado, ou seja, para que a criatura crescesse e contemplasse Deus em sua majestade. ${ }^{49}$

\section{Conclusão}

As investigações que envolvem a Teologia e as Ciências da Religião nos nossos dias se deparam com movimentos crescentes de polarizações ideológicas, fundamentalismos bíblicos e sectarismos religiosos. Inevitavelmente, há consequências para os resultados obtidos nas pesquisas que denotam os limites provocados pelos contextos de matizes apologéticas. Normalmente, isso se verifica por propostas reducionistas ou pelo frágil apelo arbitrário da aceitação dogmática.

\footnotetext{
${ }^{46}$ AGOSTINHO, In Ev. Ioan. 24, 3.

${ }^{47}$ AGOSTINHO, In Ev. Ioan. 1, 8.

${ }^{48}$ AGOSTINHO, In Ev. Ioan. 1, 8.

${ }^{49}$ AGOSTINHO, In Ev. Ioan. 1, 13.
} 
As propostas dos Padres da Igreja e, com relevante importância, de Agostinho nos inspiram a expandir os limites hermenêuticos do conteúdo da fé. Não apenas dos textos bíblicos, mas também da doutrina cristã, podem surgir elementos originais em função de um diálogo interdisciplinar que nos permita enxergar mais amplamente as luzes de Deus que incidem sobre a nossa vida e a nossa história.

Ainda é atual e relevante a exortação de levantar os olhos para as montanhas, a fim de alcançar a salvação que Deus de lá nos traz. As montanhas continuam a existir e são necessárias onde ainda houver colinas. Além do que nos relatou Agostinho, hoje as montanhas são os líderes, os bispos, os pastores, os teólogos, a moral, o dogma, o sentido religioso etc., pois para lá ainda acorrem os pequenos em busca de ajuda. Só haverão de encontrála e, em função disso, crescer espiritualmente se não se chocarem contra os arrecifes da pretensão e da soberba humana.

O nosso auxílio está no nome do Senhor, que fez o céu e fez a terra! (Sl $124,8)$.

\section{Referências bibliográficas}

AGOSTINO. Discorsi [341-400]: su argomenti vari. Roma: Editrice Città Nuova, 1989. (Opera Omnia, XXXIV).

AGOSTINO. La dottrina cristiana. Roma: Editrice Città Nuova, 1992. (Opera Omnia, VIII).

AGOSTINO. Opere Antiariane. Un discorso di parte ariana. Contro un discorso di parte ariana. Conferenza con Massimino. Polemica com Massimino. Roma: Editrice Città Nuova, 2000. (Opera Omnia, XII/2).

AGOSTINHO. A doutrina cristã: Manual de exegese e formação cristã. São Paulo: Paulus, 2002. (Patrística, 17).

AGOSTINHO. Comentários aos Salmos. São Paulo: Paulus, 2008. (Patrística, 9/2).

ATHANASE D'ALEXANTRIE. Sur l'Incarnation du Verbe. Introduction, Texte Critique, Traduction, Notas et Index. Paris: Les Éditons du Cerf, 1973. BÍBLIA de Jerusalém. Nova ed. rev. e ampl. 2. impr. São Paulo: Paulus, 2003. BISCHOFF, B. Paleografia Latina: Antichità e medioevo. Padova: Editrice Antenore, 1992. (Medioevo e Umanismo, 81). 
BORGEN, P. The Gospel of John: More Light from Philo, Paul and Archaeology. The Scriptures, Tradition, Exposition, Settings, Meaning. Leiden / Boston: Brill, 2014.

CANTALAMESSA, R. Dal kerygma al dogma. Studi sulla cristologia dei Padri. Milano: Vita e Pensiero, 2006.

CHERUBINI, P. Forme e modelli della tradizione manoscritta della Bibbia. Vaticano: Scuola Vaticana di Paleografia, Diplomatica e Archivistica, 2005.

CHERUBINI, P.; PRATESI, A. Paleografia Latina: Tavole. Città del Vaticano: Scuola Vaticana di Paleografia, Diplomatica e Archivistica, 2004.

DENZINGER, H. Compêndio dos símbolos, definições e declarações de fé e moral. Traduzido com base na 40a edição alemã (2005), aos cuidados de Peter Hünermann. São Paulo: Paulinas / Loyola, 2007.

IRINEU DE LIÃO. Contra as Heresias: denúncia e refutação da falsa gnose. São Paulo: Paulus Editora, 2014.

KOESTER, H. Gospels and Gospel Traditions. In: GREGORY, A. F.; TUCKETT, C. M. (Orgs.). Trajectories through the New Testament and the Apostolic Fathers. Oxford: Orford University Press, 2005. p. 27-44.

KYSAR, R. Giovanni, il vangelo indomabile. Torino: Claudiana Editrice, 1993. LACTANTIUS. Divine Institutes: Translated with an introduction and notes by Anthony Bowen and Peter Garnsey. Liverpool: Liverpool University Press, 2003. MAZZEO, M. Vangelo e lettere di Giovanni. Introduzione, esegesi e teolgia. Milano: Pauline, 2007.

MOSETTO, F. Esegesi agostiniana di Gv 9. Parola di Vita, n.29, p. 473480, 1984.

ORIGÈNE. Commentaire sur s. Jean. Texte grec avant-propo. Traduction et notes par Cécile Blanc. Paris: Les Éditions du Cerf, 1966. Tome I (Livres I-V). SIMONETTI, M. Studi di Cristologia Postnicena. Roma: Institutum Patristicum Augustinianum, 2006. (Studia Ephemeridis Augustinianum, 98).

STUDER, B. Augustinus De Trinitate: Eine Einführung. Paderborn: Ferdinand Schöningh, 2005.

TRAPÈ, A. I termini "natura" e "persona" nella teologia trinitária di S. Agostino. Augustinianum, v.13, n.3, p. 577-587, 1973. 
WEINANDY, T. G. The Apostolic Christology of Ignatius: the Road to Chalcedon. In: GREGORY, A. F.; TUCKETT, C. M. (Orgs.). Trajectories through the New Testament and the Apostolic Fathers. Oxford: Orford University Press, 2005. p. 71-84.

\author{
André Luiz Rodrigues da Silva \\ Doutor em Teologia e Ciências Patrísticas pelo \\ Instituto Patrístico Agostiniano \\ Docente do Departamento de Teologia da Pontificia \\ Universidade Católica do Rio de Janeiro \\ Rio de Janeiro / RJ - Brasil \\ E-mail: leleur@yahoo.it
}

Recebido em: 31/01/19 Aprovado em: 31/08/19 